\title{
Molecular characterization of cytidine monophospho-N-acetylneuraminic acid hydroxylase (CMAH) gene and frequency of blood types in stray cats of İzmir, Turkey
}

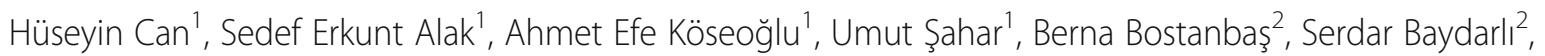
Mert Döşkaya ${ }^{3}$ and Cemal Ün ${ }^{1 *}$

\begin{abstract}
Background: Cytidine monophospho-n-acetylneuraminic acid hydroxylase (CMAH) gene associated with blood groups in cats encodes CMAH enzyme that converts Neu5Ac to Neu5Gc. Although variations in CMAH gene of pedigree cats have been revealed, the presence/lack of them in non-pedigree stray cats is unknown. Therefore, the present study aimed to investigate the variations in CMAH gene and the quantity of Neu5Ac and Neu5Gc on erythrocytes of non-pedigree stray cats (n:12) living in İmir, Turkey. Also, the frequency of blood types was determined in 76 stray cats including 12 cats that were used for $\mathrm{CMAH}$ and Neu5A/Neu5Gc analysis.

Results: In total, 14 SNPs were detected in 5'UTR as well as in exon 2, 4, 9, 10, 11 and 12 of CMAH gene. Among these SNPs, $-495 \mathrm{C}>\mathrm{T}$ in $5^{\prime} \mathrm{UTR}$ was detected for the first time as heterozygous in type A and AB cats, and homozygous and heterozygous in type $B$ cats. The remaining 13 that have been detected in previous studies were also found as homozygous or heterozygous. Both Neu5Gc and Neu5Ac were detected in type A and AB cats. In type B cats, only Neu5Ac was detected. Among two type AB cats, the level of Neu5Ac was found higher in cat carrying heterozygous form (T/C) of 1392T > C. The prevalence of type B cats (67.1\%) was higher than others.

Conclusions: The presence of a new SNP as well as previous SNPs indicates that more variations can be found in stray cats with a more comprehensive study in the future. Also, the high prevalence of type B cats demonstrates the possible risk of neonatal isoerythrolysis among stray cats living in İzmir, Turkey.
\end{abstract}

Keywords: CMAH gene, Blood typing, Stray cats, Turkey

\section{Background}

The blood group system of cats was initially reported in the early 1900's. In later years, three different blood types, called type $\mathrm{A}, \mathrm{B}$ and $\mathrm{AB}$, were demonstrated in cats. Genetic dominance among the three different blood types in cats has been reported as $\mathrm{A}>\mathrm{a}^{\mathrm{ab}}>\mathrm{b}$. According

\footnotetext{
*Correspondence: cemaluen@gmail.com

${ }^{1}$ Faculty of Science Department of Biology Molecular Biology Section, Ege University, Bornova, 35040 İmir, Turkey

Full list of author information is available at the end of the article
}

to this, $\mathrm{AA}, \mathrm{Aa}^{\mathrm{ab}}$ and $\mathrm{Ab}$ genotypes can occur in Type $\mathrm{A}$ cats, $\mathrm{a}^{\mathrm{ab}} \mathrm{a}^{\mathrm{ab}}$ and $\mathrm{a}^{\mathrm{ab}} \mathrm{b}$ genotypes in Type $\mathrm{AB}$ cats and $\mathrm{bb}$ genotype in Type B cats [1].

Determination of blood types in cats is important in veterinary clinical practice since blood type incompatibility causes transfusion reactions related to severe haemolytic anaemia, anaphylactic shock, and death [2]. In addition to transfusion reactions, neonatal isoerythrolysis can also occurred in cats when type $A$ or type $A B$ kittens are born from a type $B$ queen [3]. Both

C C The Author(s). 2021 Open Access This article is licensed under a Creative Commons Attribution 4.0 International License, which permits use, sharing, adaptation, distribution and reproduction in any medium or format, as long as you give appropriate credit to the original author(s) and the source, provide a link to the Creative Commons licence, and indicate if changes were made. The images or other third party material in this article are included in the article's Creative Commons licence, unless indicated otherwise in a credit line to the material. If material is not included in the article's Creative Commons licence and your intended use is not permitted by statutory regulation or exceeds the permitted use, you will need to obtain permission directly from the copyright holder. To view a copy of this licence, visit http://creativecommons.org/licenses/by/4.0/ The Creative Commons Public Domain Dedication waiver (http://creativecommons.org/publicdomain/zero/1.0/) applies to the data made available in this article, unless otherwise stated in a credit line to the data. 
transfusion reactions and neonatal isoerythrolysis are caused by high anti-A antibody levels found in B type cats $[4,5]$. According to data from several studies associated with blood typing in cats, type $\mathrm{A}$ is the most prevalent blood group compared to type $B$ and $A B$. For example, it has been reported in many surveys that more than $90 \%$ of domestic cats are type A [6, 7]. The frequency of type B varies substantially from 0 to $59 \%$ in the distinct geographic regions. In contrast to type $\mathrm{A}$ and $B$, the prevalence of type $A B$ is generally less than $1 \%$ worldwide [3].

The presence of different sialic acid residues on erythrocytes gives rise to different blood types in cats. Sialic acids that are expressed from echinoderms to mammals are mostly found as the terminal sugars of cell surface glycolipids and glycoproteins. There are more than 50 sialic acids derived from three main forms which are called N-acetylneuraminic acid (Neu5Ac), Nglycolylneuraminic acid (Neu5Gc) and 2-keto-3- deoxynonulosonic acid (KDN) [8]. Among them, the predominant sialic acids on most mammalian cells are Neu5Gc and Neu5Ac [9]. The Neu5Gc is expressed in a lot of mammals, except humans because of a deletion in the coding region of CMAH (cytidine monophospho-Nacetylneuraminic acid hydroxylase) gene [10]. Type A cats have mainly Neu5Gc and small amount of Neu5Ac, while type B cats have only Neu5Ac [11]. Type AB cats have both Neu5Gc and Neu5Ac at similar quantities [12]. It is stated that CMAH enzyme encoded by $C M A H$ gene determines the type of sialic acid on erythrocytes by converting Neu5Ac to Neu5Gc in cats [13]. Accordingly, CMAH enzyme is active in type A cats while it is absent or nonfunctional in type B cats [1].

$C M A H$ gene has been molecularly characterized among different cat populations and several single nucleotide polymorphisms (SNPs) $(-539 \mathrm{G}>\mathrm{A},-468 \mathrm{~A}>\mathrm{G}$, $-371 \mathrm{C}>\mathrm{T}, \quad-217 \mathrm{G}>\mathrm{A}, \quad-108 \mathrm{G}>\mathrm{A}, \quad$ c.139 $\mathrm{C}>\mathrm{T}$, c.141 C $>$ T, c.142G $>$ A, c.179G $>$ T, c.187 A $>$ G, c.213 A $>$ G, c.268T $>$ A, c.327 A $>$ C, c.364 $\quad$ C $>$ T, c.374 C $>$ T, c.376G $>$ A, c.501G $>$ A, c.593 A $>$ C, c.636G $>$ A, c.868 A $>$ C, c.898 A $>$ G, c.933 A $>$ G, c.933delA, c.993 A $>$ G, c.1158T $>$ C, $\quad$ c.1218T $>$ C, $1269 \mathrm{G}>\mathrm{A}, \quad$ c.1322delT, c.1342G $>$ A, c.1392T $>$ C, c.1398G $>$ T, c. $1452 \mathrm{~T}>\mathrm{C}, \quad$ c. $1458 \mathrm{~T}>\mathrm{C}, \quad$ c. $1603 \mathrm{G}>\mathrm{A}$, c.1662G $>$ A) have been detected [1, 14-17]. In addition to these SNPs, there is an $18 \mathrm{bp}$ insertion in 5'UTR region. Among these variations, some have also been associated with specific blood type/types. For example, 18 bp insertion has been reported to be specific for $b$ allele found in type $B$ cats as homozygous or in type $A$ or $A B$ cats as heterozygous [1].

There is no sufficient research about the presence/ prevalence of these variations or their association with specific blood groups for stray cats of Turkey, except our previous study showing the presence of $18 \mathrm{bp}$ insertion only in two of 791 stray cats [18]. Therefore, the present study aimed to investigate the presence of these variations in non-pedigree stray cats of İzmir, Turkey and their associations with blood group and the quantity of Neu5Ac and Neu5Gc on erythrocytes. To address these purposes, routine immunological blood typing was performed for 76 stray cats and among them, blood samples of 12 cats [A (n:5); B (n:5); AB (n:2)] were used for molecular characterization of $C M A H$ gene.

\section{Results}

\section{Prevalence of blood types}

Among 76 stray cats, 52 of them were female $(68.42 \%)$, 24 were male $(31.57 \%)$. Conventional slide test showed that 23 of them were type A (30.26\%), 51 of them were type $B(67.1 \%)$ and the remaining two were type $A B$ $(2.63 \%)$. There was not a statistical difference associated with prevalence of blood groups between female and male cats $(P>0.05)$.

\section{Polymorphisms in CMAH gene}

$C M A H$ gene analysis was performed using DNA samples belonging to 12 stray cats with known blood group (Table 1). During the CMAH gene analysis, 5'UTR region (including exon 1) as well as 14 exons (from exon 2 to exon 15 including 3' UTR regions) were sequenced and analysed for SNPs. According to the results obtained, a total of 14 SNPs was detected in CMAH gene. The regions carrying SNPs were 5'UTR as well as exon 2, 4, 9, 10, 11 and 12 (Table 2). Among these SNPs, one of them caused by a cytosine-thymine substitution $(-495 \mathrm{C}>\mathrm{T})$ in 5'UTR was detected for the first time as heterozygous in type $\mathrm{A}$ and $\mathrm{AB}$ cats, and homozygous and heterozygous in type B cats. The remaining 13 SNPs that have been detected in previous study were also

Table 1 Blood group and some phenotypic results of analysed stray cats for characterization of CMAH gene

\begin{tabular}{lll}
\hline Sex & Color & Blood group \\
\hline Female & Black & $\mathrm{AB}$ \\
Female & Black-White & $\mathrm{AB}$ \\
Female & Gray & $\mathrm{A}$ \\
Female & Calico & $\mathrm{A}$ \\
Female & Calico & $\mathrm{A}$ \\
Male & Tabby (White) & $\mathrm{A}$ \\
Female & Calico & $\mathrm{A}$ \\
Female & Black-White & $\mathrm{B}$ \\
Female & Tabby & $\mathrm{B}$ \\
Female & Tabby (White) & $\mathrm{B}$ \\
Male & Black & $\mathrm{B}$ \\
Male & Tabby (White) & $\mathrm{B}$ \\
\hline
\end{tabular}


Table 2 Polymorphisms detected in the CMAH gene in stray cats of Izmir

\begin{tabular}{|c|c|c|c|c|c|c|c|c|c|c|c|c|c|c|}
\hline \multirow[t]{2}{*}{ Blood type } & \multicolumn{4}{|l|}{ 5' UTR } & \multicolumn{3}{|l|}{ Exon 2} & \multirow{2}{*}{$\begin{array}{l}\text { Exon } 4 \\
\text { A327C }^{\mathrm{e}}\end{array}$} & \multirow{2}{*}{$\begin{array}{l}\text { Exon } 9 \\
\text { A993G }^{\text {d }}\end{array}$} & \multicolumn{2}{|l|}{ Exon 10} & \multicolumn{2}{|l|}{ Exon 11} & \multirow{2}{*}{$\begin{array}{l}\text { Exon } 12 \\
T 1458 C^{d} \\
\end{array}$} \\
\hline & ${ }^{\mathrm{a} C} \mathrm{C}-495 \mathrm{~T}$ & $A-468 G^{b}$ & $C-371 T^{b}$ & $G-108 A^{b}$ & ${\mathrm{C} 139 \mathrm{~T}^{\mathrm{C}}}$ & $\mathrm{G} 179 \mathrm{~T}^{\mathrm{d}}$ & $\mathrm{A} 187 \mathrm{G}^{\mathrm{d}}$ & & & $\mathrm{T} 1158 \mathrm{C}^{\mathrm{e}}$ & $\mathrm{T} 1218 \mathrm{C}^{\mathrm{d}}$ & G1269A & $\mathrm{T}_{1392 \mathrm{C}^{\mathrm{d}}}$ & \\
\hline$A B$ & $C T$ & $\mathrm{AG}$ & $C T$ & GA & $\mathrm{CT}$ & GT & AG & $A C$ & $\mathrm{AA}$ & CC & TC & GG & TC & TC \\
\hline$A B$ & $C T$ & AG & $C T$ & GA & $C T$ & GT & AG & $A C$ & AA & CC & TC & GG & CC & TC \\
\hline A & $\subset T$ & GG & $C T$ & GG & $\mathrm{CT}$ & GT & AG & CC & AA & CC & TC & GG & TC & $\mathrm{CC}$ \\
\hline A & $C T$ & GG & $C T$ & GG & $\mathrm{CT}$ & GT & $\mathrm{AA}$ & CC & AA & $C C$ & TC & GG & TC & $C C$ \\
\hline A & $C T$ & AG & $C T$ & GG & $\mathrm{CT}$ & GT & AG & CC & AA & CC & TC & GG & TC & $C C$ \\
\hline A & $C T$ & AG & $C T$ & GA & $\mathrm{CT}$ & GT & $\mathrm{AA}$ & CC & AA & CC & TC & GA & TC & TC \\
\hline A & $C T$ & AG & $C T$ & GA & $C T$ & GT & AG & CC & AA & CC & TC & GG & CC & TC \\
\hline B & $C T$ & AG & CT & GG & CT & GT & $\mathrm{AA}$ & CC & AG & $\mathrm{CC}$ & TC & GG & CC & TC \\
\hline B & $C T$ & AG & $C T$ & GA & $\mathrm{CT}$ & GT & $\mathrm{AA}$ & CC & AG & CC & TC & GG & CC & TC \\
\hline B & $\pi$ & GG & $\pi$ & GA & $\mathrm{CT}$ & GT & $\mathrm{AA}$ & CC & AG & CC & TC & GG & $\mathrm{CC}$ & CC \\
\hline B & $\pi$ & GG & $\pi$ & GA & $C T$ & GT & $\mathrm{AA}$ & CC & AA & CC & TC & GG & $\mathrm{CC}$ & CC \\
\hline B & $C T$ & AG & $\mathrm{CT}$ & GG & $\mathrm{CT}$ & GT & $\mathrm{AA}$ & CC & AG & CC & TC & GG & CC & TC \\
\hline
\end{tabular}

${ }^{a}$ shows the SNP that has been detected in this study for the first time

b [1]

c [17]

d $[15]$

e $[14]$

found as homozygous or heterozygous (Table 2). In addition, it was found that homozygous form of T1392C polymorphism was detected for the first time in type $A B$ cat when compared to previous studies (Table 3). Interestingly, 18 bp insertion (AACGAGCAACCGAAGCTG) reported in 5'UTR region in type B cats was not detected in any type of cats.

An association of the detected polymorphisms with cat blood types were also analysed and homozygous form $(\mathrm{T} / \mathrm{T})$ of the $-495 \mathrm{C}>\mathrm{T}$ polymorphism detected in this study was found among only in type B cats. Among the polymorphisms previously determined in the literature, homozygous form of the $-371 \mathrm{C}>\mathrm{T}$ polymorphism was found among only in type $\mathrm{B}$ cats whereas heterozygous form $(\mathrm{A} / \mathrm{C})$ of the c.327 $\mathrm{A}>\mathrm{C}$ polymorphism was detected only in type $\mathrm{AB}$ cats. In addition, only homozygous form of the c.1158T $>\mathrm{C}$ polymorphism were detected in all three blood groups.

\section{Type and amount of sialic acids in blood groups}

During this study, Neu5Ac and Neu5Gc and their levels were also investigated in cats with known blood type using the LC-MS/MS system. According to the results obtained, both Neu5Gc and Neu5Ac were detected in type $A$ and $A B$ cats. In type $B$ cats, only Neu5Ac was detected. $m / z$ ratios and fragment ions detected for Neu5Ac and Neu5Gc were given in Table 4. The highest Neu5Ac level $(4.53 \mu \mathrm{g} / \mathrm{g})$ was among type B cats whereas the highest Neu5Gc level $(4.39 \mu \mathrm{g} / \mathrm{g})$ was detected among type A cats. When levels of Neu5Gc and Neu5Ac were compared within each blood group, the level of Neu5Ac was found higher in one of the two $A B$ type cats. As these two cats were compared in terms of polymorphisms, $\mathrm{AB}$ type cat carrying homozygous form $(\mathrm{C} / \mathrm{C})$ of $1392 \mathrm{~T}>\mathrm{C}$ polymorphism in exon 11 had lower Neu5Ac than the other $A B$ type cat carrying heterozygous form $(\mathrm{T} / \mathrm{C})$ of $1392 \mathrm{~T}>\mathrm{C}$ polymorphism. No association was found between the SNPs and the amounts of Neu5Gc and Neu5Ac detected in type A or B cats.

\section{Discussion}

Determination of blood types in cats is important for clinical practices because of transfusion reactions and neonatal isoerythrolysis $[2,3]$. Both transfusion reactions and neonatal isoerythrolysis are related to type $\mathrm{B}$ cats having high titer anti-A antibody $[4,5]$. In our study, the prevalence of type B cats was found higher $(67.1 \%)$ when compared to type A cats. In Turkey, the prevalence results associated with type B vary according to cat breeds. For example, in a previous study, the prevalence of type B cats was found higher than type A cats among Turkish Van cats. Also, type B prevalence (46.4\%) was found nearly equal to type A (53.6\%) in Turkish Angora cats [2]. In another study, the prevalence of type B cats was found as $35.9 \%, 32.6 \%, 30.5 \%$, and $6.1 \%$ in İstanbul, İzmit, Kırıkkale and Giresun, respectively, among non-pedigree cats [3]. These findings and our results indicate that there might be a possible risk for neonatal isoerythrolysis among pedigree cats (Turkish Van and Angora) and stray cats living in İzmir, İstanbul, İzmit and Kırıkkale provinces of Turkey.

$C M A H$ gene that is associated with blood group system has been studied in cats for about 15 years. To date, several SNPs as well as an 18 bp insertion have been detected by sequencing $C M A H$ gene. Among these variations, some of them have also been associated with 
Table 3 Comparison of the SNPs detected in this study with previous studies

\begin{tabular}{|c|c|c|c|c|c|c|c|}
\hline \multirow[t]{2}{*}{ SNPs } & \multicolumn{3}{|c|}{ The present study results } & \multicolumn{3}{|c|}{ Previous studies results } & \multirow[t]{2}{*}{ References } \\
\hline & $A$ & B & $A B$ & $A$ & B & $A B$ & \\
\hline C-495T & CT & $C T, \Pi T$ & $\mathrm{CT}$ & - & - & - & The present study \\
\hline A-468G & $A G, G G$ & $A G, G G$ & $A G$ & NP & NP & NP & [1] \\
\hline \multirow[t]{2}{*}{ C-371T } & $\mathrm{CT}$ & $C T, T$ & $\mathrm{CT}$ & $\mathrm{CC}, \mathrm{CT}$ & $\pi$ & $\mathrm{CC}, \mathrm{CT}$ & {$[1]$} \\
\hline & & & & CC & $\mathrm{CC}, \mathrm{CT}, \mathrm{TT}$ & $\mathrm{CC}, \mathrm{CT}$ & {$[15]$} \\
\hline G-108A & $\mathrm{GG}, \mathrm{GA}$ & $\mathrm{GG}, \mathrm{GA}$ & GA & NP & NP & NP & [1] \\
\hline \multirow[t]{3}{*}{ С139Т } & CT & CT & $\mathrm{CT}$ & $\mathrm{CC}, \mathrm{CT}$ & $\mathrm{CC}, \mathrm{CT}$ & $C C, C T$ & {$[17]$} \\
\hline & & & & $\mathrm{CC}$ & $\mathrm{CC}, \mathrm{CT}$ & $\mathrm{CC}$ & [15] \\
\hline & & & & $\mathrm{CC}, \mathrm{CT}$ & $C C, C T, T$ & $C C, C T$ & {$[16]$} \\
\hline \multirow[t]{2}{*}{ G179T } & GT & GT & GT & GG & $\mathrm{GG}, \mathrm{GT}$ & GG & {$[15]$} \\
\hline & & & & $\mathrm{GG}, \mathrm{GT}$ & $\mathrm{GG}, \mathrm{GT}, \mathrm{TT}$ & $\mathrm{GG}, \mathrm{GT}$ & {$[16]$} \\
\hline \multirow[t]{2}{*}{ A187G } & $A A, A G$ & AA & $A G$ & AA & $A A, A G$ & $A G$ & [15] \\
\hline & & & & $\mathrm{AA}, \mathrm{AG}, \mathrm{GG}$ & AA & $A A, A G$ & {$[16]$} \\
\hline \multirow[t]{2}{*}{ A327C } & CC & CC & $A C$ & $A A, A C$ & $A A, A C, C C$ & CC & [15] \\
\hline & & & & $\mathrm{AA}, \mathrm{AC}, \mathrm{CC}$ & $A A, C C$ & $A A, A C, C C$ & [16] \\
\hline \multirow[t]{2}{*}{ A993G } & $\mathrm{AA}$ & $A A, A G$ & $\mathrm{AA}$ & $A A, G G$ & $A A, A G$ & $A G, G G$ & [15] \\
\hline & & & & $\mathrm{AA}, \mathrm{AG}, \mathrm{GG}$ & $\mathrm{AA}, \mathrm{AG}, \mathrm{GG}$ & $A A, A G$ & [16] \\
\hline \multirow[t]{2}{*}{ T1158C } & CC & $\mathrm{CC}$ & CC & $\pi, T C$ & $\mathrm{TC}, \mathrm{CC}$ & CC & [15] \\
\hline & & & & $\mathrm{TT}, \mathrm{TC}, \mathrm{CC}$ & $\Pi$ T, CC & CC & [16] \\
\hline \multirow[t]{2}{*}{ T1218C } & $\mathrm{TC}$ & $\mathrm{TC}$ & $\mathrm{TC}$ & $\pi$ & $\pi, T C$ & $\pi$ & [15] \\
\hline & & & & $\pi, T C$ & $\mathrm{TT}, \mathrm{TC}, \mathrm{CC}$ & TT, TC & [16] \\
\hline \multirow[t]{2}{*}{ G1269A } & $\mathrm{GG}, \mathrm{GA}$ & GG & GG & GG & $\mathrm{GG}, \mathrm{GA}, \mathrm{AA}$ & $\mathrm{GG}, \mathrm{GA}$ & [15] \\
\hline & & & & $\mathrm{GG}, \mathrm{GA}$ & $G G, G A, A A$ & $\mathrm{GG}, \mathrm{GA}, \mathrm{AA}$ & [16] \\
\hline \multirow[t]{2}{*}{ T1392C } & $\mathrm{TC}, \mathrm{CC}$ & $\mathrm{CC}$ & $\mathrm{TC}, \mathrm{CC}$ & $\mathrm{CC}, \mathrm{TC}$ & $\mathrm{TT}, \mathrm{TC}, \mathrm{CC}$ & $\mathrm{TC}$ & [15] \\
\hline & & & & $\mathrm{TC}, \mathrm{TT}, \mathrm{CC}$ & $\mathrm{TT}, \mathrm{TC}, \mathrm{CC}$ & $\mathrm{TT}, \mathrm{TC}$ & [16] \\
\hline \multirow[t]{2}{*}{ T1458C } & $\mathrm{TC}, \mathrm{CC}$ & $\mathrm{TC}, \mathrm{CC}$ & TC & $\Pi, C C$ & $\mathrm{TT}, \mathrm{TC}, \mathrm{CC}$ & $T \mathrm{~T}, \mathrm{TC}$ & [15] \\
\hline & & & & $\Pi \mathrm{T}, \mathrm{TC}, \mathrm{CC}$ & $\Pi$ T, CC & $\Pi$ & [16] \\
\hline
\end{tabular}

NP Not present

specific blood types. For example, Bighignoli et al. (2007) reported the 16 SNPs as well as an 18 bp insertion in $C M A H$ gene of cats and among these, $-217 \mathrm{G}>\mathrm{A}$, $-371 \mathrm{C}>\mathrm{T}$, c.142G > A (originally G139A), c.268T > A (originally T265A), c.1603G > A (originally G1600A) and $18 \mathrm{bp}$ insertion were found to be specific to blood group [1]. Accordingly, homozygous forms of these variations specific to type B cats or heterozygous forms could be found in $\mathrm{b}$ allele carrier cats such as heterozygous type $A$ and $A B$ cats. In our study, C-371T was detected in type $A, B$ and $A B$ cats as heterozygous $(C / T)$. Moreover, homozygous form of the $-371 \mathrm{C}>\mathrm{T}$ polymorphism was found among only in type $B$ cats. The remaining four SNPs $(-217 \mathrm{G}>\mathrm{A}$, c.142G > A, c. $268 \mathrm{~T}>\mathrm{A}$, c.1603G > A) and $18 \mathrm{bp}$ insertion were not detected in stray cats. These results demonstrate that there may be different variations in the CMAH gene between popular cat breeds and stray cats, and some of them are more common among popular cat breeds as well as being specific to blood groups. This assertion is actually supported by a study showing the presence of c.364 $\mathrm{C}>\mathrm{T}$ polymorphism in only Ragdoll cat breeds with AB blood group [14].

Table 4 Relative retention times and characteristic ions of Neu5Ac and Neu5Gc analysed by LC-MS/MS

\begin{tabular}{|c|c|c|c|c|}
\hline \multirow[b]{2}{*}{ Sialic acid } & \multirow[b]{2}{*}{ Retention Time } & \multirow[b]{2}{*}[\mathrm{M}+\mathrm{H}]{$^{+}$} & \multicolumn{2}{|c|}{ Collision-induced dissociation fragments } \\
\hline & & & {$\left[\mathrm{M}+\mathrm{H}-\mathrm{H}_{2} \mathrm{O}\right]^{+}$} & Fragments $(\mathrm{m} / \mathrm{z})$ \\
\hline Neu5Gc & 2,8 & 442 & 424 & $313-295-268-283-229$ \\
\hline Neu5Ac & 3,2 & 426 & 408 & $313-295-283-229$ \\
\hline
\end{tabular}


In a different study, c.179G $>\mathrm{T}$, c.187 A $>\mathrm{G}$, c. $1218 \mathrm{~T}>\mathrm{C}$ and c.1662G $>\mathrm{A}$ polymorphisms were detected in $C M A H$ gene of type $\mathrm{B}$ cats as homozygous or heterozygous. c.187 $\mathrm{A}>\mathrm{G}$ was also detected in type $\mathrm{AB}$ cats as heterozygous [15]. In our study, c.179G $>\mathrm{T}$ and c.1218T > C were found in type $A, B$ and $A B$ cats as heterozygous as well as c.187 A $>\mathrm{G}$ in only type $\mathrm{A}$ and $\mathrm{AB}$ as heterozygous. c.1662G $>\mathrm{A}$ was not found in stray cats. In the following study conducted by Kehl et al., (2018), a total of 29 SNPs including 13 new polymorphisms (c.141 C>T, c.213 A $>$ G, c.374 C $>$ T, c.376G $>$ A, c. $501 \mathrm{G}>\mathrm{A}, \quad$ c.593 A $>\mathrm{C}, \quad$ c.636G $>\mathrm{A}$, c.868 A > C, c.898 A $>$ G, c.933delA, c.1322delT, c.1342G > A and c.1452 C > T) were detected in different cat breeds analysed. Among these SNPs, some of them were detected in homozygous or heterozygous forms in Turkish Angora cats [16]. The Turkish Angora cats that are one of the oldest cat breeds have originated from Ankara region of Turkey which is relatively close to İzmir, our study area. Therefore, previous results of Angora cats were compared with the analysed stray cats. Accordingly, homozygous or heterozygous forms of coding region polymorphisms (c.139 $\mathrm{C}>\mathrm{T}$, c.179G $>\mathrm{T}$, c.187 A > G, c.327 A > C, A993G, T1158C, T1218C, G1269A, T1392C and T1458C) detected in our study were observed as coherent in both groups. Moreover, $18 \mathrm{bp}$ insertion that has not been detected in our study was found only in one type B cat among eight Turkish Angora cats analysed [16]. These findings indicated that coding region polymorphisms detected in our study can be prevalent in Turkey whereas $18 \mathrm{bp}$ insertion was rare. Our previous study showing the prevalence of $18 \mathrm{bp}$ insertion as $0.25 \%(2 / 791)$ also supports this result. [18].

Polymorphisms detected in CMAH gene have also been used as a genetic marker in the determination of blood groups. For example, Tasker et al. (2014) used two SNPs [G142A (original G139A) and C139T (original $\mathrm{C} 136 \mathrm{~T})]$ to determine blood groups and reported that serological results were $96 \%$ compatible with those of molecular methods [17]. Contrary to this, among these two SNPs, only one (C139T) was found in stray cats as heterozygous and did not show any correlation with blood groups. Therefore, the present results invalidate the genotype-blood group scheme for stray cats. $-495 \mathrm{C}>\mathrm{T}$ that is detected for the first time in our study and - $371 \mathrm{C}>\mathrm{T}$ were found as homozygous $(\mathrm{T} / \mathrm{T})$ in same two type $\mathrm{B}$ cats. Also, heterozygous form $(\mathrm{A} / \mathrm{C})$ of the $327 \mathrm{~A}>\mathrm{C}$ polymorphism was detected only in type AB cats. Although these results indicate a very limited relation with blood groups in stray cats, there is a need for additional studies analysing more stray cats with type $B$ and $A B$. Moreover, no previously detected polymorphism which is known to be related to blood groups showed any exact relationship with blood groups in stray cats (Table 2).
In cats, types of sialic acids related to blood groups are known. Accordingly, type A cats have Neu5Gc while type B cats have Neu5Ac. Neu5Ac can also be found at low levels in type $A$ cats. Type $A B$ cats have both Neu5Gc and Neu5Ac at similar levels. In our study, types of sialic acid were found as coherent with literature in blood groups. However, among two AB cats analysed, Neu5Ac was found higher (nearly 4 folds) in one. As the two cats were compared in terms of polymorphisms, only single position $(1392 \mathrm{~T}>\mathrm{C})$ was different. Depending on this, it was thought that the homozygous form of the polymorphism $(\mathrm{C} / \mathrm{C})$ can change Neu5Ac level in type $\mathrm{AB}$ cats because SNPs found in promotor, intron or exon regions of any gene have potential to change the level of protein/enzyme expressions [19].

\section{Conclusions}

The findings demonstrate the possible risk of neonatal isoerythrolysis among stray cats because of high prevalence of type $\mathrm{B}$ cats. In $C M A H$ gene, identification of a new polymorphism $(-495 \mathrm{C}>\mathrm{T})$ and the presence of previously identified polymorphisms indicate that more polymorphisms can be found in stray cats with a more comprehensive study. Moreover, the results also indicate that polymorphisms that have been found as coherent with blood groups in previous studies are not acceptable for stray cats in this region.

\section{Methods}

\section{Collection of blood samples}

Blood samples were collected from healthy stray cats (n: 76) which were brought to Veterinary Clinics in Narl1dere province of İzmir, Turkey for sterilization purposes. 1-2 $\mathrm{ml}$ of blood sample was obtained from tissue material that was removed from the anesthetized cats during sterilization, inserted into $5 \mathrm{ml}$ tubes with EDTA and kept at $+4{ }^{\circ} \mathrm{C}$ until used.

\section{Blood typing}

Blood typing was performed for 76 blood samples by conventional slide test as described [20]. Briefly, a serum sample belonging to type $B$ cat as anti-A reagent and Lectin Triticum vulgaris $(1 \mathrm{mg} / \mathrm{ml})$ as anti-B reagent were used. $50 \mu \mathrm{l}$ of anti-A and anti-B reagents were individually added to a slide and both of them were gently mixed with $25 \mu \mathrm{l}$ of blood sample by a pipette. After 5 min, blood types were detected by observing the presence of agglutination. Among 76 blood samples, 12 of them [A (n:5); B (n:5); AB (n:2)] were also studied by a commercial immunochromatographic strip method [Alvedia rapid-test (LabTest $\mathrm{A}+\mathrm{B}$ ) to confirm blood type results. These confirmed samples were used for analysis of $C M A H$ gene. 
PCR

DNA isolation from blood samples was conducted by PureLink Genomic DNA Mini Kit (Thermo Fisher Scientific) according to the manufacturer's instructions. During PCR, 16 different regions of $C M A H$ gene including a 5' UTR and 14 exons as well as 3'UTR were amplified using primer pairs $[14,15]$. PCR mixture contained $2 \mu \mathrm{l}$ template DNA, $12.5 \mu \mathrm{l}$ Dream Taq master mix (Thermo scientific), $1 \mu \mathrm{l}$ from each of primers $(10 \mathrm{pmol})$ and $8.5 \mu \mathrm{l}$ distilled water. The PCR amplifications were carried out under the following conditions: $2 \mathrm{~min}$ initial denaturation step at $95{ }^{\circ} \mathrm{C}$, followed by 35 cycles of $1 \mathrm{~min}$ at $95{ }^{\circ} \mathrm{C}, 45 \mathrm{~s}$ at $58{ }^{\circ} \mathrm{C}$, and $45 \mathrm{~s}$ at $72{ }^{\circ} \mathrm{C}$, and a final extension of $10 \mathrm{~min}$ at $72{ }^{\circ} \mathrm{C}$ [1]. PCR products were run through $1 \%$ agarose gel electrophoresis and visualized.

\section{Sequencing}

PCR products belonging to $C M A H$ gene were sequenced by $\mathrm{ABI} 3730 \mathrm{XL}$ and generated sequences were aligned by MEGA7.0 software to compare exons belonging to reference Felis catus CMAH gene with accession number NM_001244985.1 and to compare 5' UTR regions belonging to reference Felis catus CMAH genes with accession numbers EF127683 and EF127686.

\section{Preparation of the samples and LC-MS/MS analysis}

The determination of Neu5Ac and Neu5Gc in erythrocyte samples isolated from whole blood was carried out using modification of the methods reported by Hara et al. (1986) and Yeşilyurt et al. (2015) [21, 22]. Briefly, $30 \mathrm{mg}$ erythrocyte sample was incubated for $90 \mathrm{~min}$ at $80{ }^{\circ} \mathrm{C}$ with $0.1 \mathrm{M}$ trifluoroacetic acid (TFA) for acid hydrolysis in order to release the sialic acids. After that, released sialic acids were derivatized with DMB (1,2-Diamino-4,5-methylenedioxybenzene dihydrochloride) solution containing $1.55 \mathrm{mg} \mathrm{DMB}, 3.68 \mathrm{mg}$ sodium hydrosulfite and $50 \mu \mathrm{l} 2$-mercaptoethanol prepared in $950 \mu \mathrm{l} 0.1 \mathrm{M}$ TFA. Derivatized sialic acids were pipetted into the HPLC vial insert. The injection volume was settled to $0.3 \mu \mathrm{L}$ in the method. Commercial Neu5Ac (Sigma) and Neu5Gc (Sigma) were used as standard.

HPLC analysis was performed using an Agilent 1200 Capillary HPLC system with an ODS capillary column (Agilent ZORBAX SB-C18 1500.5 mm, 5 mm, USA). Elution was performed by isocratic mode at $20 \mu \mathrm{L} / \mathrm{min}$ using a mixture of (methanol/acetonitrile, 3:2) and water at $1: 4$ ratios. The column temperature was kept at $30^{\circ} \mathrm{C}$ during the analysis. All mass spectrometric measurements were performed on an HCT Ultra ion trap mass spectrometer (Bruker Daltonics, Bremen, Germany) equipped with an electrospray ionization (ESI) source in positive mode. Ion optics voltages, nebulizer gas, and dry gas flow rates, and the dry gas temperature were controlled by EsquireControl software 6.1. All mass spectra were acquired in the mass range $200-600 \mathrm{~m} / \mathrm{z}$, with a scan speed of $26,000 \mathrm{~m} / \mathrm{z}$ per second. Data analysis was carried out using Data Analysis software (v.3.4, Bruker Daltonics).

\section{Abbreviations \\ CMAH: Cytidine monophospho-n-acetylneuraminic acid hydroxylase; Neu5Ac: N-Acetylneuraminic acid; Neu5Gc: N-Glycolylneuraminic acid; 5'UTR: 5' untranslated region; KDN: 2-keto-3- deoxy-nonulosonic acid; SNPs: Single nucleotide polymorphisms; A: Adenine; C: Cytosine; G: Guanine; T: Thymine; TFA: Trifluoroacetic acid; DMB: 1,2-Diamino-4,5- methylenedioxybenzene dihydrochloride}

\section{Acknowledgements}

Not Applicable.

\section{Authors' contributions}

Conceived and designed the experiments: CÜ, HC. Performed the experiments: HC, SEA, AEK, US, BB, SB. Analysed the data: CÜ, HC, MD. Wrote the paper: CÜ, HC. Reviewed and edited the paper: CÜ, HC, MD. All authors have read and approved the manuscript.

\section{Funding}

This study was supported by a project given by The Scientific and Technological Research Council of Turkey (TÜBITAK) (Project number: 218Z105) to C.Ü. The funding bodies played no role in the design of the study and collection, analysis, and interpretation of data and in writing the manuscript.

\section{Availability of data and materials}

All sequences obtained from CMAH gene of stray cats were deposited into GenBank (National Center for Biotechnology Information Search database). Provided GenBank accession numbers are as follows. MW750673, MW750674, MW750675, MW750676, MW750677, MW750678, MW750679, MW750680, MW750681, MW750682, MW750683, MW750684, MW750685, MW750686, MW750687, MW750688, MW750689, MW750690, MW750691.

\section{Declarations}

Ethics approval and consent to participate

All experiments were performed under the instructions and approval of the Institutional Animal Care and Use Committee (IACUC) of Ege University for animal ethical norms (Permit number: 2010-72; 2017-008).

\section{Consent for publication}

Not applicable.

\section{Competing interests}

The authors declare no conflict of interest.

\section{Author details}

${ }^{1}$ Faculty of Science Department of Biology Molecular Biology Section, Ege University, Bornova, 35040 Izmir, Turkey. ${ }^{2}$ Department of Veterinary Affairs, Municipality of Narlıdere, Izmir, Turkey. ${ }^{3}$ Faculty of Medicine, Department of Parasitology, Ege University, Bornova, Izmir, Turkey.

Received: 21 March 2021 Accepted: 7 April 2021

Published online: 19 April 2021

\section{References}

1. Bighignoli B, Niini T, Grahn RA, et al. Cytidine monophospho-Nacetylneuraminic acid hydroxylase (CMAH) mutations associated with the domestic cat AB blood group. BMC Genet. 2007;8(1):27. https://doi.org/10.11 86/1471-2156-8-27.

2. Arikan S, Duru SY, Gurkan M, Agaoglu ZT, Giger U. Blood type A and B frequencies in Turkish Van and Angora cats in Turkey. J Vet Med A Physiol Pathol Clin Med. 2003;50(6):303-6. https://doi.org/10.1046/j.1439-0442.2003. 00536.x. 
3. Arikan S, Gurkan M, Ozaytekin E, Dodurka T, Giger U. Frequencies of blood type $A, B$ and $A B$ in non-pedigree domestic cats in Turkey. J Small Anim Pract. 2006;47(1):10-3. https://doi.org/10.1111/j.1748-5827.2006.00005.x.

4. Knottenbelt CM, Day MJ, Cripps PJ, Mackin AJ. Measurement of titres of naturally occurring alloantibodies against feline blood group antigens in the UK. J Small Anim Pract. 1999;40(8):365-70. https://doi.org/10.1111/j.1748-582 7.1999.tb03101.x.

5. Arikan \$, Gürkan M. Clinical aspects of blood transfusion in cats. Ankara Univ Vet Fak Derg. 2009;56(2):153-7.

6. Giger U, Bucheler J, Patterson DF. Frequency and inheritance of A and B blood types in feline breeds of the United States. J Hered. 1991;82(1):15-20. https://doi.org/10.1093/jhered/82.1.15.

7. Hohenhaus AE. Importance of blood groups and blood group antibodies in companion animals. Transfus Med Rev. 2004;18(2):117-26. https://doi.org/1 0.1016/j.tmrv.2003.12.003.

8. Izzetoğlu S, Şahar U, Şener E, Deveci R. Determination of sialic acids in immune system cells (coelomocytes) of sea urchin, Paracentrotus lividus, using capillary LC-ESI-MS/MS. Fish Shellfish Immunol. 2014;36(1):181-6, https://doi.org/10.1016/j.fsi.2013.10.029.

9. Samraj A, Läubli H, Varki N, Varki A. Involvement of a non-human sialic acid in human cancer. Front Oncol. 2014;4:33. https://doi.org/10.3389/fonc.2014. 00033.

10. Irie A, Koyama S, Kozutsumi Y, Kawasaki T, Suzuki A. The molecular basis for the absence of N-glycolylneuraminic acid in humans. J Biol Chem. 1998; 273(25):15866-71. https://doi.org/10.1074/jbc.273.25.15866.

11. Andrews GA, Chavey PS, Smith JE, Rich L. N-glycolylneuraminic acid and Nacetylneuraminic acid define feline blood group A and B antigens. Blood. 1992;79(9):2485-91.

12. Griot-Wenk M, Pahlsson P, Chisholm-Chait A, Spitalnik PF, Spitalnik SL, Giger $U$. Biochemical characterization of the feline AB blood group system. Anim Genet. 1993;24(6):401-7. https://doi.org/10.1111/j.1365-2052.1993.tb00352.x.

13. Merbl $Y$, Hason A, Sethon ED, Aroch I. A survey of feline AB group blood types in Israel (2007 to 2009). Isr J Vet Med. 2011;66:21-8.

14. Gandolfi B, Grahn RA, Gustafson NA, et al. A novel variant in CMAH is associated with blood type AB in Ragdoll cats. PloS One. 2016;11(5): e0154973. https://doi.org/10.1371/journal.pone.0154973.

15. Omi T, Nakazawa S, Udagawa C, et al. Molecular characterization of the cytidine monophosphate-N-acetylneuraminic acid hydroxylase (CMAH) gene associated with the feline AB blood group system. PloS One. 2016; 11(10):e0165000. https://doi.org/10.1371/journal.pone.0165000.

16. Kehl A, Heimberger K, Langbein-Detsch I, et al. Molecular characterization of blood type $\mathrm{A}, \mathrm{B}$, and $\mathrm{C}(\mathrm{AB})$ in domestic cats and a CMAH genotyping scheme. PloS One. 2018;13(9):e0204287. https://doi.org/10.1371/journal. pone.0204287.

17. Tasker S, Barker EN, Day MJ, Helps CR. Feline blood genotyping versus phenotyping, and detection of non-AB blood type incompatibilities in UK cats. J Small Anim Pract. 2014;55(4):185-9. https://doi.org/10.1111/jsa p.12180.

18. Can H, Atalay Şahar E, Döşkaya M, et al. Analysis of cytidine monophospho$\mathrm{N}$-acetylneuraminic acid hydroxylase (CMAH) gene related to neonatal Isoerythrolysis in stray cats of Izmir, Turkey. Kafkas Univ Vet Fak Derg. 2016; 22(3):355-9. https://doi.org/10.9775/kvfd.2015.14637.

19. Deng $N$, Zhou H, Fan H, Yuan Y. Single nucleotide polymorphisms and cancer susceptibility. Oncotarget. 2017;8(66):110635-49. https://doi.org/10.1 8632/oncotarget.22372.

20. Seth M, Jackson KV, Giger U. Comparison of five blood-typing methods for the feline AB blood group system. Am J Vet Res. 2011;72(2):203-9. https:/ doi.org/10.2460/ajvr.72.2.203.

21. Hara S, Yamaguchi M, Takemori Y, Nakamura M, Ohkura Y. Highly sensitive determination of $\mathrm{N}$-acetyl- and $\mathrm{N}$-glycolylneuraminic acids in human serum and urine and rat serum by reversed-phase liquid chromatography with fluorescence detection. J Chromatogr B Biomed Sci Appl. 1986;377:111-9.

22. Yeşilyurt $B$, Şahar $U$, Deveci R. Determination of the type and quantity of sialic acid in the egg jelly coat of the sea urchin Paracentrotus lividus using capillary LC-ESI-MS/MS. Mol Reprod Dev. 2015;82(2):115-22. https://doi.org/1 $0.1002 / \mathrm{mrd} .22448$

\section{Publisher's Note}

Springer Nature remains neutral with regard to jurisdictional claims in published maps and institutional affiliations.

\section{Ready to submit your research? Choose BMC and benefit from}

- fast, convenient online submission

- thorough peer review by experienced researchers in your field

- rapid publication on acceptance

- support for research data, including large and complex data types

- gold Open Access which fosters wider collaboration and increased citations

- maximum visibility for your research: over $100 \mathrm{M}$ website views per year

At $\mathrm{BMC}$, research is always in progress.

Learn more biomedcentral.com/submissions 